\title{
POLYGAMY IN THE PERSPECTIVE OF HADITH: Justice and Equality among Wives in a Polygamy Practice
}

\author{
Rahmin T. Husain', Arifuddin Ahmad², Siti Aisyah Kara³, Zulfahmi Alwi ${ }^{4}$ \\ 'State Institute for Islamic Studies (IAIN) Gorontalo, J. Sultan Amay, Pone, Limboto Bar, Gorontalo \\ 2,3,4State Islamic University (UIN) Alauddin Makassar, Jl. Sultan Alauddin No.63 Makassar, Sulawesi Selatan

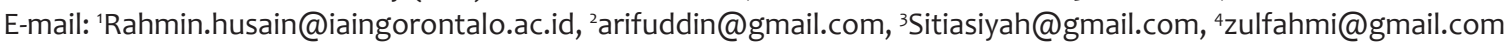

\begin{abstract}
Polygamy in the Perspective of Hadith: Justice and Equality among Wives in a Polygamy Practice. This article aims to overview some hadith[s] concerning justice and equality among wives in the practice of polygamy. This is literature-based research. In this study, documentation technique was employed in order to collect the data and used takhrij al-Hadith approach. Then, they were analysed by using descriptive analysis method. The result reveals that polygamy might be allowed in certain conditions, especially when a husband could be just and equal in a household among his wives. Practically, this requirement is somewhat challenging. Besides faith and obedience, justice and equality in a family can only be achieved if there is a high optimism, strong confidence, and good paradigm. Although some wives consider it as 'ain al-sukhty (hatred paradigm), others percieve it as 'ain al-ridha (pleased paradigm). Unfortunately, to overcome this problematic matter for polygamists in the recent day, justice and equality as the key points in a household should realistically be understood well as what the Prophet Muhammad Peace Be Upon Him (PBUH) had practiced. A positive atmosphere is likely possible to realize in a polygamous household.
\end{abstract}

Keywords: polygamy; justice; equality; hadits.

\begin{abstract}
Abstrak: Poligami dalam Perspektif Hadis: Keadilan dan Kesetaraan antar-para Istri dalam Praktik Berpoligami. Artikel ini bertujuan untuk menelaah beberapa hadis yang berkaitan dengan keadilan dan kesetaraan antarpara istri dalam praktik berpoligami. Penelitian ini merupakan penelitian pustaka. Dalam penelitian ini, teknik dokumentasi digunakan untuk mengumpulkan data dengan pendekatan takhrij al-Hadith. Selanjutnya, data tersebut dianalisis dengan menggunakan metode deskriptif-analisis. Hasil penelitian ini membuktikan bahwa poligami dibolehkan dalam keadaan tertentu, terutama jika suami dapat berlaku adil terhadap istri-istrinya. Dalam kenyataannya, praktik tersebut sulit dilakukan. Di samping keimanan dan ketaatan kepada Allah Swt, keadilan dalam rumah tangga hanya bisa dicapai jika pasangan suami istri saling optimistis, saling percaya, dan saling memiliki pandangan yang baik terhadap praktik poligami. Meskipun sebagian istri menentang praktik poligami, sebagian yang lain rida. Untuk mengatasi permasalahan tersebut, konsep keadilan dan kesetaraan sebagai kunci utama dalam rumah tangga harus dipahami dengan baik sebagaimana dicontohkan oleh Nabi Muhammad Saw sehingga tercipta keharmonisan dan kedamaian.
\end{abstract}

Kata kunci: poligami; keadilan; kesetaraan; hadis.

\section{Introduction}

The existence of polygamy's legality has always been a debatable issue with many arguing that polygamy is perceived as a human rights violation of a gender. ${ }^{1}$ Pros and cons dealing with polygamy is continuously discussed by Muslim scholars as a hot topic. Some scholars recommend polygamy as an implementation of

1 Zuraidah, "Keadilan Dalam Keluarga: Poligami," Jurnal An Nisa'a, Vol.8, No. 1, 2013, pp. 45-53. obeying Allah's command and some may refuse polygamy with some argumentations that always relates to gender inequality ${ }^{2}$. As an endless topic to talk about, polygamy is always interesting to be deliberated especially in Indonesia due to its majority of Muslim. The practice of polygamy in perspective of Quran is allowed, but it also does not recommend and obligate people to do. It is

${ }^{2}$ Haris Hidayatulloh, "Adil Dalam Poligami Perspektif Ibnu Hazm,” Religi: Jurnal Studi Islam, Vol. 6, No. 2, 2015, pp. 207-36. 
permitted with some requirements that need to be carried out, one of them is a husband can behave justly and equally to his wives ${ }^{3}$.

Many people decline polygamy because it discriminates women due to its injustice and inequality. ${ }^{4}$ Justice is a characteristic that treats something accurately and fairly by representing someone or something as that person or thing truly is, and give rights to other people who supposed to accept that even though other people are their rival. By doing so, it will create a good atmosphere for someone to be responsible without violating other people's rights. So being justice in the context of polygamy should be given equally by a husband to his wives in all aspects, such as material fulfilment, living place, and family time sharing. ${ }^{5}$ A research conducted by Sa'adah, Fitria, \& Widiastuti ${ }^{6}$ state that some groups consider polygamy as a symbol of patriarchy and the marginalization of women. On the other hand, polygamy is also regarded either as a part of faith or a human right which cannot be intervened by someone else. Faisol ${ }^{7}$ contrastingly states that the main point of polygamy is in the interpretation of the word justice and equality in behaving toward polygamous wives.

The issue related to polygamy is mainly focused on how a husband takes his responsibility in providing the materials, treating his wives similarly and taking care the household. ${ }^{8}$

\footnotetext{
${ }^{3}$ Makrum, "Poligami Dalam Perspektif Al-Qur'an," Jurnal Maghza, Vol.1, No. 9, 2016, pp. 35-50.

4 Harun Fadri, "Konsep Adil Dalam Poligami (Studi Terhadap Pemikiran Dosen Fakultas Syari'ah UIN Raden Intan Lampung)" (Universitas Islam Negeri Raden Intan Lampung, 2017).

5 Jaenuri, "Implementasi Konsep Adil Dalam Poligami Di Desa Sumberrejo Kecamatan Batanghari Kabupaten Lampung Timur," Jurnal As-Salam, Vol. IV, No. 1, 2015, pp. 103-23.

${ }^{6}$ Nurus Sa'adah, Vita Fitria, and Kurnia Widiastuti, "Poligami Dalam Lintas Budaya Dan Agama: Meta-Interpretation Approach Nurus Sa'adah”, Vol. 49,No. 2, 2015, pp. 379-499.

7 Yufni Faisol, “Konsep Adil Dalam Poligami : Telaah Pemikiran Mushthofa Al- 'Adawï Dalam Tafsir Al-Tashïl Lita ' Wïl Al-Tanzïl," International Journal Ihya' 'Ulum Al-Din, Vol. 18, No. 1, 2016, pp. 25-48, https://doi.org/10.21580/ihya.17.1.1730.

8 Abdul Hakim Bin Baharudin and Ismail Amzan Bin Satiman, "Status Hubungan Antara Isteri-Isteri Dalam Poligami: Analisis Terhadap Perbincangan Hukum-Hukum Fekah," in 3rd International Conference on Islamiyyat Studdies (IRSYAD2017), Vol. 3, 2017, pp. 130-36.
}

Moreover, Ropiah ${ }^{9}$ states that the indication of injustice and inequality a polygamy practice is a classic issue which is always attracting to be discussed both for women and men. For women, if polygamy is allowed, men will get Sharia legitimation to marry more than one woman. Meanwhile, almost all women think that polygamy is a serious problem for them. It is something that should be avoided in a household because the general characteristic of a woman wants to be the one and only wife for her husband.

As a topic discussed by Ulama, law expertise, and society, polygamy is stated in Quran as a challenge for women even it is almost impossible to be realized. Justice required in Quran is described as affection, love, and care. They cannot be measured by numbers. As a human being, people naturally cannot behave justly in giving loves and affections. It will normally happen when a husband draws his attention to one of his wives more than other wives that he has. This situation occurs out of human's control. A research conducted by Jalil ${ }^{10}$ explain that polygamy idea always remains a 'task' that needs to be finished where people should consider different perspectives caused by the different method in understanding the problem of nash. There are some people who support the legality of polygamy as a recommendation and even as an obligation starting from textual understanding of nash al-Qur'an and hadith of Prophet which hinted to be applied.

Fenske $^{11}$ argues that education in this modern era has failed to decrease the practice of polygamy. It also conveys the students to believe that polygamy is an illegal practice as what happened in Nigeria, Sierra Leone, Kenya, and Zimbabwe. In fact, the regulation of polygamy is

${ }^{9}$ Siti Ropiah, "Studi Kritis Poligami Dalam Islam (Analisa Terhadap Alasan Pro Dan Kontra Poligami)," Al-Afkar, Journal for Islamic Studies, Vol.1, No. 1, 2018, pp. 89-104, https://doi. org/10.5281/zenodo.1161566.

${ }^{10}$ Abdul Jalil, "Wanita Dalam Poligami (Studi Pemikiran Muhammad Syahrur)," Cendekia: Jurnal Studi Keislaman, Vol. 2, No. 1, 2016, pp. 1-19.

$"$ James Fenske, "African Polygamy: Past and Present iv," Journal of Development Economics ,Vol. 117, 2015, pp. 58-73, https://doi.org/10.1016/j.jdeveco.2015.06.005. 
legalized in the constitution of marriage, custom, and Islamic law. As stated by Al-Sharfi,Pfeffer, \& Miller, ${ }^{12}$ many countries in middle East, Asia, and Africa legalize polygamy although it is not practiced by all people. In Indonesia, there are many men who do polygamy without asking permission to their wife and without accomplishing his duty related to material matter and the agreement of the wife. In other words, many polygamy practices in Indonesia are done secretly or illegal.

The focus of this research is to find out how the study of hadith perceives justice and equality among wives in the practice of polygamy, and to obtain accurate information in the perspective of hadith analysed from sanad (the citations or "backings" used to verify the legitimacy of a hadith) and matn (the text of the hadith). The analyses are used to gain comprehensive understanding to the polygamist in order to treat their wives justly and equally.

\section{Method}

This is a literature-based study which aims to collect, study, and examine various books, literatures, and journals that have relevance to polygamy hadith. They are mentioned in various hadith books dealing with polygamy. The researcher only focused on the hadith of considering justice and equality for wives. In collecting the data, primary and secondary data were obtained. Primary data was collected from kutub at-Tis'ah. To find the data, the technique and the procedures of hadith study is needed. Hadith study is doing takhrij al-Hadith where the researcher investigated hadith based on first source references. Sanad and matn were also employed in explaining the data. These activities were done in order to know which hadith concerns to justice for wives in polygamy. The researcher also did rijal al-Hadith to distinguish authentic and reliable hadith[s] from unreliable hadith[s] in establishing the credibility of the narrators,

${ }^{12}$ Mohammad Al-sharfi, Karen Pfeffer, and Kirsty A Miller, "The Effects of Polygamy on Children and Adolescents : A Systematic Review," Journal of Family Studies 9400, No. March, 2016, pp. 1-15, https://doi.org/10.1080/13229400.2015.1086405. using both historic and religious knowledge. While, secondary data was obtained through books, journals, and others which has relation to references about polygamy.

In analysing the data, this study used a descriptive analytical method that aims to describe hadith in various hadith books dealing with justice to wives in a polygamy practice. A comparative analysis was also conducted to compare various hadith in treating wives of polygamy practice based on the analysis of relevant references. Subsequently, a comprehensive understanding of justice and equality among wives in a polygamy practice was obtained.

\section{Analysis of Takhrij Hadith on Polygamy}

Being fair in polygamy is, nowadays, deemed to be challenging for husbands. Thus, this problematic topic is indisputably urgent to be conducted by using hadith study. The analysis done through takhrij al-Hadith method by using Mu'jam al-mufahras li al-fadz al-hadis al-Nabawi can be seen through the following text:

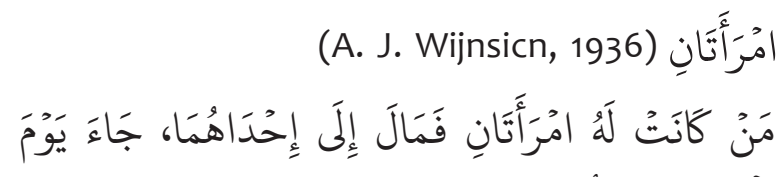

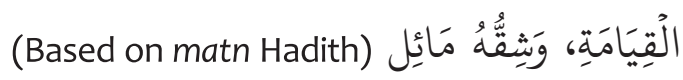

This hadith can be found in many hadith books such as in Sunan al-Darirmiy book which involves 1 story, al-nikah book chapter 24, hadith number 2252; in Sunan Abu Daud, 1 story, al-nikah book chapter 39, hadith number 2133; in Sunan al-Nasai involves 1 story, on ushrah al-nisa' book chapter 2, hadith number 8831; in Sunan Ibnu Majah involves 1 story, al-nikah book chapter 47, hadith number 1969; in Sunan al-tirmidzy involves 1 story, on abwab al-nikah chapter 42, hadith number 1141; in Musnad Ahmad Ibnu Hanbal involves 2 stories; in musnad Abi Hurairah, hadith number 7936 and 10090.

The following ayah is one of sanad and matn hadith descriptions. It is cited from Sunan AlDarimy book: Al-Darimy, 2000.

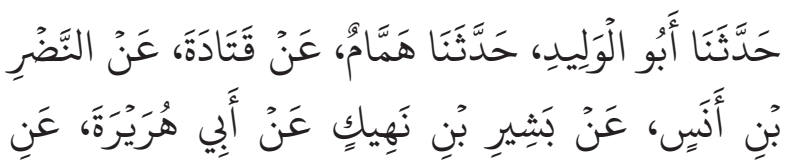




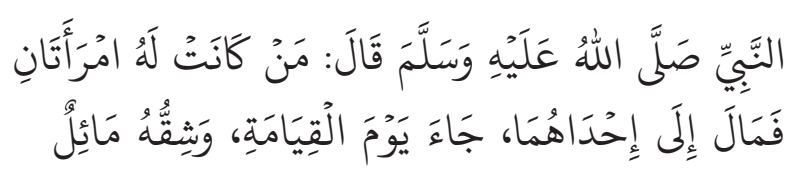

Abu al-Walid has told us, Hammam has told us from Qatadah from ibn al-Nadr ibn Anas from Bashir ibn Nahik from Abu Hurairah from Prophet Muhammad, He said that whoever has two wives and he is prefer to one of them, then he will come on the day of judgement with one of his sides leaning.

The conclusion of research result through sanad al-Darimiy is accurate (shahih). The accuracy indicates such research can be continued to matn Hadith. In comparing to its structures, textual differences are found. In at-Turmuzi narration, the word فلم يعدل means 'unfair', while the other narrations the word فمال or يميل means 'inclined to one of them'. Furthermore, in the last sentence, it contains شقه ساقط and which means 'one of his sides leaning'. However, the textual difference has slightly different meaning. It shows that the hadith were told meaningfully. This is not caused by hadith narrator that describes it tanawwu' or differently. It is proven by sanad al-Darimy narration where all the narrators have tsiqah (trusted) character and the sanad will be linked. Whereas, there is no matn structure that is adequate to Arabic grammar so it is easy to be comprehended. Matn hadith al-Darimy studied in this research is derived from syadz and illah. It leads to the quality of accurate matn al-Darimy. Since sanad and matn of the hadith are acceptable, the hadith can be considered as hujjah (regulation).

Justice is interpreted as impartial, fair, siding with the right, adhering to the truth, and not arbitrarily. It contains the meaning of equality and the absence of discrimination in any forms. Thus, one of the purposes of the traits that someone has acted fairly is if he treats everyone equally. ${ }^{13}$ The term of polygamy generally means having more than a wife. ${ }^{14}$ Hazm."

13 Hidayatulloh, “Adil Dalam Poligami Perspektif Ibnu

${ }^{14}$ Brenda R Weber, "The Epistemology of the ( Televised, Polygamous ) Closet: Progressive Polygamy, Spiritual Neoliberalism, and the Will to Visibility," Television \& New
The consequence of this practice depends on the way how a husband treats his wives justly and equally. Then, a question will come up on whether the husband is able to behave fairly to his wives or not because everyone cannot control the tendency of his heart. Justice and equality that a husband thinks is satisfactory may not be fair in wives' point of view. Most men who do polygamy in Indonesia merely satisfy their lust and desires, and not as a form of faith. Consequently, there is a tendency to be unjust to one of his wives; even they often neglect their obligations. An ironic situation is when a man is economically capable to do the practice of polygamy, but he still forces to realize it.

Being perfectly just for all polygamous wives is not an easy thing to be practiced. However, that does not mean no one can do polygamy. A man who wants to do polygamy need to consider the concept of justice and equality in terms of material and immaterial. Besides, justice in terms of material concerns to the orphans. ${ }^{15}$ Islam provides the best solution for this problem, that is "polygamy" with a prerequisite that a husband can act justly to his wives in many aspects such as food, clothing, shelter, and affection. If he is not confident or doubtful to share fairly among his wives, then one wife is enough. This can create a harmonious family with tranquillity, love, and mercy based on the purpose of marriage that Islam has embraced ${ }^{16}$. The concept of justice according to the experts of figh can be seen from physical form such as livelihood and intimacy which can be measured and regulated. In terms of feelings, justice can be appreciated from love or affection, that is something that cannot be measured definitely and cannot be owned by anyone. ${ }^{17}$ Therefore, it does not mean a man (the polygamist) cannot do justice, but

\footnotetext{
Media Journal, Vol. 17, No. 5, 2016. pp. 375-91, https://doi. org/10.1177/1527476415625175.

${ }^{15}$ HK Nawir, “Keadilan Dalam Poligami Menurut Al-Qur'an (Studi Pemikiran Tafsir M. Quraish Shihab” (Universitas Islam Negeri Alauddin Makassar, 2016).

${ }^{16}$ Zuraidah, "Keadilan Dalam Keluarga: Poligami."

17 Ropiah, "Studi Kritis Poligami Dalam Islam (Analisa Terhadap Alasan Pro Dan Kontra Poligami)."
} 
he must be able to treat their wives justly based on his abilities.

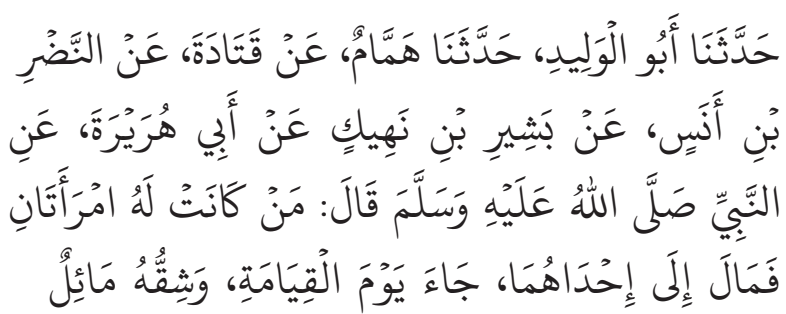

Abu al-Walid had told us, Hammam had told us from Qatadah from ibn al-Nadr ibn Anas from Bashir ibn Nahik from Abu Hurairah, from The Prophet states: "Whoever has two wives and he is prefer to one of them, then he will come on the day of judgement with one of his sides leaning".

A husband who cannot be able to be fair to all his wives will get a punishment from Allah as the threat mentioned in the hadith above. As explained by a statement narrated by Abu Hurairah, Rasulullah PBUH an ultimatum that states "Whoever has two wives and he is prefer to one of them, then he will come on the day of judgement with one of his sides leaning ". The phrase مال in the hadith above has two meanings, مال which means reprehensible and not reprehensible. According to al-Khattabi a tendency assumed is an excessive tendency to one wife. Considering that all wives have the same rights, it is obligatory for a husband to treat his wives fairly including in the case of mua'asyarah (husband's promise to satisfy his wife's sexual needs) and shuhbah (accompany). Meanwhile, مال which is impeccable is the tendency of the heart. Heart or qalb Sali'mini has full of love because of Allah. Qalb Salim is being able to have a good spirituality in relation to Allah Swt.

According to Muhammad Yusuf Qardlawi, the word "inclined or inclined" means to underestimate the rights of his wife ". A man who has two or more wives must treat his wives equally. In this case, the equality of rights is crucial. These rights include the fulfilment of the wife's primary and secondary needs in the form of food, clothing, shelter, health insurance and others. Wife's rights must be given equally and proportionally as the rights and obligations of husband and wife are not only a necessity but a need to achieve harmony in the household.

The feminist movement and gender issues that echoed in the 19th century or in the early 2oth century had a major influence on the paradigm of most women. Throughout Islamic history that is more than 13 centuries, it has never recorded opinions from all existing madhhab from the most conservative to the most liberal who denounced polygamy, even forbid it. The starting point is the penetration of the Western culture into the Islamic world through modernization since the $19^{\text {th }}$ century. Sami Zubaidah wrote in his book "Law and Power in the Islamic World". She was inspired by Western values, modernists and Islamic reformers who emerged in the century agreed to view the teachings and Sunna of the Prophet in polygamy as a symbol of the backwardness of Islam and his people. For them, getting rid of polygamy is a must for men if they really want to move forward and be civilized. Asghar Ali frankly encouraged Muslims not hesitate to forbid polygamy in order to take away Islamic negative point of view from Western that views Islam as a religion that did not respect the rights and dignities of women. This is where the movement of criminalization of polygamy was launched as a jihad of civilization to encounter the backwardness of the Muslim countries.

Muhammad Abduh was the first Ulama in Islamic history who criticized the practice of polygamy done by irresponsible polygamist. The criticism was later used as a theological reference for opponents of polygamy in the future. It was also in line with modern feminists that was normatively prohibiting this practice. At the end of his review of polygamy, he still gave high appreciation to the polygamists who accomplished their responsibilities as well as their behaviours were still commendable in gaining their closeness to Allah Swt: "They are the people who are not contemptible with polygamy that allows a man to marry 2 up to 4 women as it is acceptable in Syariah".

An investigation conducted by some Muslim scholars had shown that there were some 
people who call their names as anti-polygamist, tried to propagate and revealed polygamy as something bad to practice. At the same time, the feminists kept silence to the phenomena of adultery which was commonly happened either in Western civilization or in Indonesia. Likewise, some media had involved actively in film projects and soap operas to instil the character of hatred towards polygamy, especially among women. As a result, it made them accept their husband to be sinful of adultery rather than having second marriage. They prefered to have a husband that has an affair with other women to unregistered marriage. Therefore, those husband thought that they were free from responsibility to do justice for their wife.

Jonas ${ }^{18}$ states that the practice of polygamy undermines women's self-esteem and it is also contrary to human rights. So, the Convention on the Elimination of all Forms of Discrimination against Women (CEDAW) strongly opposes polygamy. The CEDAW Committee had urged the countries to take legislative steps to enforce and prohibit this practice in their territory. It had also been considered as a violation of Article 12 of CEDAW and guaranteed women's health rights to prevent the possibility of increasing the spread of HIV and other venereal diseases. Likewise, Huang \& Ommundsen ${ }^{19}$ claim that the practice of polygamy depresses wives and makes unhappy marriages. A family that was polygamous often fell apart because a husband shares his love from one wife to another. In addition, there was something interesting that happened in Nigeria based on Adenike finding. ${ }^{20}$. As she conducted a survey from several students from polygamous

${ }^{18}$ Obonye Jonas, "The Practice of Polygamy under the Scheme of the Protocol to the African Charter on Human and Peoples ' Rights on the Rights of Women in Africa : A Critical Appraisal," Journal of African Studies and Development, Vol. 4, No. 5, 2012, pp. 142-49, https://doi.org/10.5897/JASD12.027.

19 Zhong Huang and Wenche Ommundsen, "Poison, Polygamy and Postcolonial Politics: The First Chinese Australian Novel," Journal of Postcolonial Writing 9855, No. February, 2017, pp. 1-12, https://doi.org/10.1080/17449855.201 6.1230170 .

20 Adesehinwa Olayinka Adenike, "Effects of Family Type (Monogamy or Polygamy) on Students ' Academic Achievement in Nigeria," Academic Journals, Vol. 5, No. 7, 2013, pp 153-56, https://doi.org/10.5897/IJPC10.012. family, it showed that they had better academic achievements than their friends who came from monogamous family. This might happen because polygamous family develops a positive attitude towards problems related to social aspect, so it does not affect their academic achievement.

Islam has provided opportunities for polygamy, but this religion has also asked a man to obey fundamental aspect of polygamy to be just and equal to their wives. Behaving justice as a requirement of polygamy is the intention and strong confidence of Muslim men to be fair to their wives. A man who is not able to fulfil the rights of their wives should not marry more than one. As the word of God:

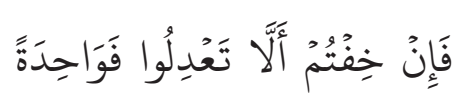

If you are afraid to not being fair, then one wife is enough

Polygamy system regulated in Islam is truly humanistic and morals. Relationship among wives are intertwined with kinship and companionship. Children were also born from a legitimate family and they have a legal status. Thus, their rights are more protected and maintained by the law. In the future, they will become part of the successor in this nation. As stated by Chin ${ }^{21}$, from the historical context of Indonesia, an understanding is needed to fully respect cultural and social issues that have relevance to the practice of polygamy. This is supported by various findings conducted by researchers showing that polygamy has a historical story that has been embedded in religious and ideological beliefs and cultural traditions in Indonesia. This is appropriate with the statement of ${ }^{22}$ who mentions the practice of polygamy is usually supported by religion and custom that commonly has different rules in various countries starting from the prohibition of practicing polygamy

${ }^{21}$ Grace V S Chin, "Imagined Subjects: Polygamy , Gender and Nation in Nia Dinata 's Love for Share," Journal of International Women's Studies, Vol. 13, No. 3, 2012, pp. 137-52.

${ }^{22}$ Dureti Abate Fulas, "The Legal Framework Regulating Polygamy in Ethiopia: An Assessment In Light of Liberal Feminist Legal Theory and International Human Rights Law" (Lund University, 2018). 
and allowing it legally. Similarly, the theory of feminist law has a different point of view by allowing this practice as a potential stepping stone for women's equality or the expression of one's choice.

The practice of polygamy among Muslims was originally from the authority of a verse in the Quran which states that men can marry up to four wives. This is also supported by hadiths that are mentioned in various books of hadith. Therefore, for those who are polygamist or want to practice polygamy, they must interpret the concept of justice and equality in treating wives as well as respecting their rights and obligations without being discriminated. Therefore, it can be concluded that basically, justice and equality can still be realized in a polygamous household that should be built on a high attitude of optimism, strong self-confidence, a healthy paradigm based on faith and piousness. The prophet has become a role model in this area. The intended prerequisites need to be understood with the practice of polygamous conducted by the Prophet. So, by prohibiting polygamy, this also means blaming what has been done by the prophet, Muhammad PBUH. In addition, both husband and wives has to know their rights and obligations in order to hinder obstacles in their household. They should also understand a new paradigm that can create new attitudes and skills in managing polygamous households. This is very possible, because as long as a wife looks at polygamy as 'ain al-sukhty (the view of hatred, no matter how much effort to be fair, all will be closed with the perspective of 'ain al-sukhti). On the other hand, if a wife perceives polygamy as 'ain al-ridha (the view of sincerity), then justice and equality will not be hard to be realized. Occasionally, changing a woman's perspective (paradigm) toward polygamy is far more difficult than realizing justice and equality itself. This rarely gets the attention of the polygamist in the recent days.

\section{Critical Reflection on Polygamy}

Islam strongly emphasizes the principles of justice and equality in polygamy which is not just a matter of material things or time sharing among wives but it also includes love and affection that become foundations in a household. It is in line with what Zaidi ${ }^{23}$ said that men and women can enjoy peace, comfort and happiness in marriage only if the relationships are established on the principles of truth and fairness. These can inspire mutual trust, love, and mercy between husband and wife. Nonetheless, there is an irony on the existence of polygamy permits extracted from the Quran and hadith. It becomes misinterpreted, accepted and utilized by men in Muslim societies throughout the world in other forms only as a mere satisfaction of lust.

Similar to Zaidi, Fajar ${ }^{24}$ explains that Islam gives a great attention to aspects of justice and equality. It can be seen in the Quran that there are many terms which mention laws of polygamy, especially stating that justice is a necessity that must be realized in all aspects. One of the objectives of Sharia is to bring justice to human life. In Sharia polygamy, the concept of justice should be realized from psychological, sociological, legal, and even fiqh justice. Islam asks every people to optimize their potential for being justice because all wives will psychologically get hurt if they see their husbands in contact with other women for the following reasons: (1) it will discourage wife's loyal love to her husband. Generally, a wife trusts and loves her husband wholeheartedly so that she has no more room to love other men, (2) a wife will feel herself inferior as if her husband did so because she was unable to fulfil his biological satisfaction. The inferior feeling is increasingly becoming a psychological problem, especially if it is under pressure from the family, (3) there will come a form of internal conflict in the family, either among wives, between wives and stepchildren, or among children of different mothers. An unhealthy feeling among wives will naturally ask them to compete each other. This

${ }^{23}$ Terasa Zaidi, "Polygamy: In The Perspective of Islam," Social Sciences International Research Journal,Vol. 2, No. 1, 2016, pp. 201-5.

24 M Samson Fajar, "Keadilan Dalam Hukum Islam (Tinjauan Multidisipliner Dalam Kasus Poligami)," Al-'Adalah XII, No. 1, 2014, pp. 33-48. 
can be happened when a husband pays more attention to young wives than other wives. In fact, it is commonly occurred after marriage where the husband abandons his wives and children from a previous marriage. Then, he will break up with his first wives and children. This will certainly cause serious social problems in the community.

A study conducted by Riyandi ${ }^{25}$ says that polygamy is permissible in religion with a condition that the man can be fair to all wives both physically and mentally, and to their children in all household needs. Islam does not easily allow people to do polygamy because this religion is highly upholding the values of justice in the family. This concerns with the dignity of women who have full rights of their husbands. Various rights of a wife must be accomplished by husband so that there is no arbitrarily intimidation and abuse.

Moreover, Zuhrah ${ }^{26}$ describes justice as the basic principle of polygamy. Clothing, food, shelter, love, affection and social interaction among his wives will not be shared justly. So the husband still takes care of himself and not overdoes it with one of his wives. This can be seen in the historical fact that prophet Muhammad PBUH, friends of him, tabi'in and many Muslims who practice polygamy said that a man who capable acts justly and equally in polygamy is a man who has goodness over good. This is specifically personal and general for a wider community.

Fadri $^{27}$ additionally explain that doing justice in polygamy is very difficult to live in today's world because those who want to practice of polygamy are mostly just seeking worldly satisfaction. The only just concept can only be lived by the prophet Muhammad $\mathrm{PBUH}$, while humans can only apply close to

${ }^{25}$ S Riyandi, "Syarat Adanya Persetujuan Isteri Untuk Berpoligami (Analisis Ushul Fikih Syafi'lyyah Terhadap UndangUndang Perkawinan Nomor 1 Tahun 1974)," Jurnal IImiah Islam Futura, Vol. 15, No. 1, 2015, pp. 111-42.

${ }^{26}$ Fatimah Zuhrah, "Adil Berpoligami: Analisis Hukum Keluarga Islam Di Indonesia," Jurnal Ri'ayah, Vol. 2, No. 2, 2017, pp. 79-88.

${ }^{27}$ Fadri, "Konsep Adil Dalam Poligami (Studi Terhadap Pemikiran Dosen Fakultas Syari’ah UIN Raden Intan Lampung).” fair. Islam allows polygamy for men, but they must give justice to all of his wives not only one or two of them. If they do so, other wives will be jealous. The point is that some Ulama agree on the issue of polygamy, except the expressions or ways of interpreting that has different meaning. Allah Swt justifies for a man to marry two, three, up to four wives, as long as he can be just and equal to all his wives, but if he fears that he shall not be able to deal justly (with them), then only one woman is enough. That is nearer to prevent him from doing injustice.

Based on a study conducted by Arifah, Sholehah, \&Hardianto ${ }^{28}$, some group of people believe that polygamy is an unjust action on the relationship of a husband and a wife. In this practice, wife's position will turn into an object, whereas she should eventually be the subject in a family that is positioned equally in obtaining their rights with their husbands. Because of this process, polygamy always involves a woman to feel hurt even though no matter how hard they try and accept the situation, especially if there has been no confirmation and approval before. A wife will feel his rights and dignity have been taken as a woman. According to Heath, Braimoh \& Gouweloos ${ }^{29}$, justice in polygamy will not be found because it will only harm women, children and society.

Mustofa $^{30}$ states that polygamy can be a solution of immorality such as adultery and provide protection for women. In terms of biological, male sexual tendencies will continue to exist until they are old, meanwhile the ratio of women is much more in quantity compared to men. This thing causes different opinions from classical and contemporary Ulama. The majority of classical and medieval Ulama argue

${ }^{28}$ Anis Nur Arifah, Reniyadus Sholehah, and Triwahju Hardianto, "Poligami Kiai: Praktek Poligami Kiai Di Kota Jember Dalam Pandangan KHI Dan Gender," Jurnal Yudisia, Vol.7, No. 1, 2016, pp. 121-45.

${ }_{29}$ Melanie Heath, Jessica Braimoh, and Julie Gouweloos, "Judging Women's Sexual Agency: Contemporary Sex Wars in the Legal Terrain of Prostitution and Polygamy," Journal OfWomen in Culture and Society, Vol. 42, No. 1, 2016, pp. 199-223.

30 Muhamad Arif Mustofa, "Poligami Dalam Hukum Agama Dan Negara," Al-Imarah: Jurnal Pemerintahan Dan Politik Islam, Vol. 2, No. 01, 2017, pp. 47-58. 
that polygamy can absolutely be done and limited to a maximum of four wives. While the majority of contemporary Muslim Ulama and modern Muslim legislation allow polygamy with the requirements that are not easy in certain circumstances. Moreover, Muslims and contemporary Ulama argue that polygamy is forbidden for reasons that are not in accordance with the basic principles of Islamic religion and for gender reasons.

The same study was conducted by Yusefri ${ }^{31}$ who reviewed the opinion of Siti Musdah Mulia, who stated that polygamy marriage was haram lighairih and seemed not only very brave but also unique with some following reasons. First, the arguments used by Musdah Mulia to refuse polygamy consisting of normative and nonnormative arguments. The normative argument was in the form of the verse of the Quran, al-Nisâ ' [4] verse 129, and the hadith of the Prophet Muhammad PBUH which contained the prohibitions and threats for people who did the practice of polygamy. Whereas, non-normative arguments were: (1) polygamy was contrary to the principle and purpose of marriage, that is mawaddah wa rahmah (love and affection). These principles are built on the foundation of love, loyalty, and affection that is without edge, as mentioned in the Quran surah al-Rum [30] verse 21. It can only be realized through monogamy; (2) no one will realize the criteria of justice and equality in polygamy, except the Prophet Muhammad PBUH, and; (3) polygamy nowadays is more harmful than its benefits.

Second argument, in the view of Musdah Mulia, Q.S al-Nisâ ' [4] verse 3 which was always used as the theological and normative basis for justifying the permissibility of polygamy, not explaining in the context of marriage, but in the context of the protection of orphans and women from the unjust treatment. The acceptability of polygamy which can be seen literally in the verse is only a temporary solution for Muslims in the early days, so that they are free from unlimited marriages which are condemned

${ }^{31}$ Yusefri, "Hukum Poligami Menurut Siti Musdah Mulia* (Suatu Tinjauan Metodologis)” 3, No. 2, 2015, pp. 201-36. because they are full of injustice The verse contains more on the threat of doing polygamy rather than to allow it, or in essence the verse contains a warning that human avoids all forms of behaviour that is unfair and indiscriminate, especially in a marriage. As for the behaviour of the Prophet's polygamy, she considered it not as a Sunna of religious teachings but it was based on the interests of dakwah, politics and Islam action. This was obviously different from polygamy in the recent days which is generally based on lust and biological interests. While justice that is demanded by al-Nisâ' [4] verses 3 and 129 , is justness in terms of material (born) and immaterial. For the methodological aspects, in understanding verses Q.S al-Nisâ' [4] verses 3 and 129, as well as the practice of polygamy of the Prophet PBUH, she used a systematic method and a contextual analysis approach, and was not bound by the written text.

Third, the term "haram li ghairi" meant by Musdah Mulia was something that was prohibited (haram) because of the negative excesses caused by external factors. The term and concept of haram lighairihi is a part of illegitimate law which is mentioned in the Islamic law theory of taklifi. She used the law theory that has already presented in that study. Furthermore, the haram ligahirihi of polygamy in her point of view is fighiyah rule "dar'u almafasit muqaddamu' ala jalb mashalih ". This rule was actually appeared from the theory of maqashid al-syari'ah which was developed by the ulama in the study of ushul figh. It means that a methodology in "implementing" the law of polygamy using the "istinbath ishtilahi method". Therefore, the analytical approach was contextual and philosophical. By using this method and approach, she seemed unattached or even left the text or lafazh zahir nash. The theories, methods and approaches used by Musdah were in contrast to Ulama of classical ushul figh who generally prioritized the study of texts from the context of the text.

In contrast to Wahbah Zuhaili in a research conducted by Hafidzi ${ }^{32}$, he states a concept of

32 Anwar Hafidzi, "Prasyarat Poligam Dalam Kitab Fiqih Islam Dan Kompilasi Hukum Islam Perspektif Mashlahah 
polygamy that was viewed from the maslahah approach. It raises two reasons why God gives a limitation in polygamy. First, a husband is able to be fair in the zahir approach where he can provide a living, and sharing the appropriate time in fulfilling the rights of his wife and children. Second, he is able to pay for a household expenditure so that everyone feels comfortable and peaceful in carrying out their lives. From several hadith that explain the rules of polygamy, Firdaus in the study of Hafidzi conducted the meaning of polygamy hadiths. He found that there were about 83 histories which explained the practice of polygamy. His findings stated that the Prophet emphasized the principles of justice with polygamy livelihood and ethics. His instructions were not in the form of orders or recommendations, but only the ability to do so with very strict requirements such as consideration in the ability of justice and its benefit. The aim was to avoid patriarchal practices and eliminate gender inequalities that marginalized women, for example in the case of Khadijah. Through the study of the Prophet life, he did not commit polygamy only after Khadijah died, which is according to medical scientific studies, male sexual desire decreased at the age of 50 years.

\section{Conclusion}

Various studies have supported and opposed the practice of polygamy in the concept of justice and equality for wives. Then, with the dynamics of the development of human life from all aspects were pro and contra to the realization of justice in the practice of polygamy. There should be further studies and further understanding of justice concept toward wives who experience polygamous in a hadith perspective. So, it was still opened for other researchers to study in other perspectives because this study was not perfect yet. In order to know the reasons of doing polygamy, Shepard's finding ${ }^{33}$ has recommended a result

Mursalah," Al-Daulah: Jurnal Hukum Dan Perundangan Islam, Vol. 7, No. 2, 2017, pp. 366-92.

33 L D Shepard and L D Shepard, "And Psychiatric Sciences: The Impact of Polygamy on Women's Mental that was necessary to conduct further research on the psychological impact of the wives in the practice of polygamy so as to obtain information in building preventive approaches and the intervention of current practice of polygamy.

\section{References}

Al-Darimi, Abu Muhammad ibn 'Abdullah ibn 'Abdurrahman ibn al-Fadl ibn Bahram, Sunan al-Darimi, Arab Saudi: Dar al-Mughni li alNashr wa al-Tauzi', 2000.

Adenike, Adesehinwa Olayinka, "Effects of Family Type (Monogamy or Polygamy) on Students' Academic Achievement in Nigeria." Academic Journals,Vol. 5, No. 7, 2013. https://doi. org/10.5897/IJPC10.012.

Al-Sharfi, Mohammad, Karen Pfeffer, and Kirsty A Miller, "The Effects of Polygamy on Children and Adolescents : A Systematic Review." Journal of Family Studies 9400, No. March, 2016. https://doi.org/10.1080/13229400.201 5.1086405 .

Arifah, Anis Nur, Reniyadus Sholehah, and Triwahju Hardianto, "Poligami Kiai: Praktek Poligami Kiai Di Kota Jember Dalam Pandangan KHI Dan Gender." Jurnal Yudisia 7, No. 1, 2016.

Baharudin, Abdul Hakim Bin, and Ismail Amzan Bin Satiman, "Status Hubungan Antara IsteriIsteri Dalam Poligami: Analisis Terhadap Perbincangan Hukum-Hukum Fekah." In 3rd International Conference on Islamiyyat Studdies (IRSYAD2017), Vol. 3, 2017.

Chin, Grace V S, "Imagined Subjects : Polygamy, Gender and Nation in Nia Dinata's Love for Share." Journal of International Women's Studies, Vol. 13, No. 3, 2012.

Fadri, Harun, “Konsep Adil Dalam Poligami (Studi Terhadap Pemikiran Dosen Fakultas Syari'ah UIN Raden Intan Lampung)." Universitas Islam Negeri Raden Intan Lampung, 2017.

Health: A Systematic Review The Impact of Polygamy on Women's Mental Health : A Systematic Review," Epidemiology and Psychiatric Sciences , Vol.22, No. March, 2012, 2015, pp. 4762, https://doi.org/10.1017/S2045796012000121. 
Faisol, Yufni, “Konsep Adil Dalam Poligami : Telaah Pemikiran Mushthofa Al-'Adawï Dalam Tafsir Al-Tashïl Lita' Wîl Al-Tanzîl." International Journal Ihya' 'Ulum Al-Din ,Vol. 18, No. 1, 2016. https://doi.org/10.21580/ihya.17.1.1730.

Fajar, M Samson, "Keadilan Dalam Hukum Islam (Tinjauan Multidisipliner Dalam Kasus Poligami).” Al-'Adalah, Vol. XII, No. 1, 2014.

Fenske, James, "African Polygamy : Past and Present." Journal of Development Economics, Vol. 117, 2015. https://doi.org/10.1016/j. jdeveco.2015.06.005.

Fulas, Dureti Abate, "The Legal Framework Regulating Polygamy in Ethiopia: An Assessment In Light of Liberal Feminist Legal Theory and International Human Rights Law." Lund University, 2018.

Hafidzi, Anwar, “Prasyarat Poligam Dalam Kitab Fiqih Islam Dan Kompilasi Hukum Islam Perspektif Mashlahah Mursalah." Al-Daulah: Jurnal Hukum Dan Perundangan Islam, Vol. 7, No. 2, 2017.

Heath, Melanie, Jessica Braimoh, and Julie Gouweloos, “Judging Women's Sexual Agency: Contemporary Sex Wars in the Legal Terrain of Prostitution and Polygamy." Journal OfWomen in Culture and Society, Vol. 42, No. 1, 2016.

Hidayatulloh, Haris, "Adil Dalam Poligami Perspektif Ibnu Hazm." Religi: Jurnal Studi Islam, Vol. 6, No. 2, 2015.

Huang, Zhong, and Wenche Ommundsen, "Poison, Polygamy and Postcolonial Politics : The First Chinese Australian Novel." Journal of Postcolonial Writing 9855, No. February, 2017. https://doi.org/10.1080/17449855.2016.1230170. Jaenuri, "Implementasi Konsep Adil Dalam Poligami Di Desa Sumberrejo Kecamatan Batanghari Kabupaten Lampung Timur." Jurnal As-Salam IV, No. 1, 2015.

Jalil, Abdul, "Wanita Dalam Poligami (Studi Pemikiran Muhammad Syahrur)." Cendekia: Jurnal Studi Keislaman 2, No. 1, 2016.

Jonas, Obonye, "The Practice of Polygamy under the Scheme of the Protocol to the African Charter on Human and Peoples ' Rights on the Rights of Women in Africa : A Critical
Appraisal." Journal of African Studies and Development, Vol. 4, No. 5, 2012. https:// doi.org/10.5897/JASD12.027.

Makrum, "Poligami Dalam Perspektif Al-Qur'an.” Jurnal Maghza, Vol. 1, No. 9, 2016.

Mustofa, Muhamad Arif, "Poligami Dalam Hukum Agama Dan Negara." Al-Imarah: Jurnal Pemerintahan Dan Politik Islam, Vol. 2, No. 01, 2017.

Nawir, HK, “Keadilan Dalam Poligami Menurut Al-Qur'an (Studi Pemikiran Tafsir M. Quraish Shihab." Universitas Islam Negeri Alauddin Makassar, 2016.

Riyandi, S, "Syarat Adanya Persetujuan Isteri Untuk Berpoligami (Analisis Ushul Fikih Syafi'lyyah Terhadap Undang-Undang Perkawinan Nomor 1 Tahun 1974)." Jurnal Ilmiah Islam Futura, Vol. 15, No. 1, 2015.

Ropiah, Siti, "Studi Kritis Poligami Dalam Islam (Analisa Terhadap Alasan Pro Dan Kontra Poligami)." Al-Afkar, Journal for Islamic Studies, Vol. 1, No. 1, 2018. https://doi. org/10.5281/zenodo.1161566.

Sa'adah, Nurus, Vita Fitria, and Kurnia Widiastuti, "Poligami Dalam Lintas Budaya Dan Agama: Meta-Interpretation Approach Nurus Sa'adah”, Vol. 49, No. 2, 2015.

Shepard, L D, and L D Shepard, "And Psychiatric Sciences: The Impact of Polygamy on Women's Mental Health : A Systematic Review The Impact of Polygamy on Women's Mental Health : A Systematic Review." Epidemiology and Psychiatric Sciences, Vol. 22, No. March, 2012, 2015. https://doi.org/10.1017/ S2045796012000121.

Weber, Brenda R, "The Epistemology of the (Televised, Polygamous) Closet : Progressive Polygamy, Spiritual Neoliberalism, and the Will to Visibility." Television \& New Media Journal 17, no. 5 (2016): 375-91. https://doi. org/10.1177/1527476415625175.

Yusefri, “Hukum Poligami Menurut Siti Musdah Mulia* (Suatu Tinjauan Metodologis)", Vol. 3, No. 2, 2015.

Zaidi, Terasa, "Polygamy: In The Perspective of Islam." Social Sciences International Research Journal 2, No. 1, 2016. 
MADANIA Vol. 23, No. 1, Juni 2019

Zuhrah, Fatimah, "Adil Berpoligami: Analisis Hukum Keluarga Islam Di Indonesia." Jurnal Ri'ayah, Vol. 2, No. 2, 2017.
Zuraidah, "Keadilan Dalam Keluarga: Poligami." Jurnal An Nisa'a, Vol. 8, No. 1, 2013. 